\title{
Remediated Pedagogies? The Secret Life of Six Year Olds.
}

Richard Berger \& Ashley Woodfall.

Introduction.

In 2015, a new television programme debuted on Channel 4 in the UK. The Secret Life of Four Year Olds was based on a pilot earlier from the previous year, and this time around was augmented by The Secret Life of Five Year Olds and The Secret Life of Six Year Olds, respectively. The programme makers stated that this offered different sites of developmental comparisons, across three distinct agegroups, and by doing so appropriated the conventions (age-not-stage) and contexts (the classroom) familiar to UK television audiences - particularly those with children of their own.

At first glance there was nothing particularly innovative about Secret Life...; historically is not a new idea to create a television show around children, and Secret Life... had its origins in a rich history of related longitudinal programming: Michael Apted's Seven Up! (1964 - present) returned to its participants every seven years, from the 1960s onwards, but rather than any pedagogic appeal, the programme compared the adults' contemporary lives to their childhood aspirations and dreams, with often quite moving moments. Similarly, Robert Winston's on-going Child of Our Time (2000 - present) project followed the lives of 25 children, born at the millennium, but here in a way which mobilised scientific discourses rather than pedagogic ones; the participants genes and their environments were far more important than their social and cultural capital, or their education.

What is interesting about such programming, is that they attempt to offer-up a child's lived lifeexperience, in a way which bisects entertainment and education. While Secret Life... is presented as an entertaining piece of reality television, as a companion piece to the same channel's Googlebox (2013 - present), the implication is that this is 'pedagogy by stealth'. The educational and child development experts on hand appropriate some of the scholarly cachet of Seven Up! and Child of Our Time. The 'immediacy' of children reacting to recent news events seems an important aspect of its 
reception. Here, the experts on-hand lend the series an amount of professional credibility; the 'Take Part' section of the channel's website - which invites new participants - states that: "The entire process will be observed and monitored by leading scientists and child psychologists who will provide occasional comment on the children's stages of development". So, while Secret Life... cannot help being used to mobilise pedagogic discourses, and in this offers nothing new, the way in which the programme has been received is more interesting.

Almost immediately, reviewers picked-up on the combative relationships between the children, the language used to convey anger as well as budding romances and alliances; one of the educational experts featured in the programme, Paul Howard-Jones, even went as far as saying: "A single day for them is more gruelling than a week's worth of EastEnders" (in Woods, 2015). The set-up is simple: a group of same-age children, who have never met before, are brought together in an entirely contrived school-like setting. While two teachers are present throughout filming, the children are largely left alone, and their interactions are captured by a combination of (sometimes visible) handheld and hidden cameras. The viewer can at times detect prompting by the programme makers, and the children are also interviewed individually.

The two educational experts are in a separate room, and offer commentary on events, for the television audience. The programme was generally very well received in the UK press, with reviewers making constant comparisons with other genres: The Daily Mail called the show, "Big Brother for little people" (London \& Johnston, 2015); The Guardian compared Secret Life... to another reality TV show, known for its contrived conflicts, Geordie Shore (Wollaston, 2015); similarly, The Sun made comparisons with Made in Chelsea and The Only Way is Essex (Cox, 2015); however it was The Independent newspaper which pointed out that while entertaining, the programmed offered little in the way of insight (Wyatt, 2015).

While the programme was presented as a "ground-breaking" experiment, it was a step-back in terms of how we understand children's interaction with the world, but perhaps a step-forward in providing yet more evidence that pedagogy - that is the scholarship of teaching and learning - needs to undergo 
a process of "remediation" (Bolter \& Grusin, 2000). Secret Life... maybe be as contrived and artificial as many discredited effects studies (see Barker \& Petley, 1997) but the claims made by it are worth closer scrutiny; commentators (both from the programme itself and in reviews) expressed surprise that the older children had quite a sophisticated understanding and knowledge of global events, and at times acted out 'scenes' from news stories.

In one episode of The Secret Life of Six Year Olds, one child drew a picture of a parent without arms, because they were always on their mobile phone and did not "deserve" the means to use it. In another scene, children played a game in which they 'reported' on a terrorist attack on a train in Paris. Two of the children even 'performed' as Sky News presenters. Newspaper coverage seemed astonished at this, and suggested, somewhat surprise, that children could learn from the news, could talk intelligently about upsetting events, and learn through play: "In the latest episode ...it is revealed how international terrorism has become part of their playground games, and they are happy to talk to one another about the bad things they have seen on the news" (Waterlow, 2015). In this chapter, we ask: why would they not?

\section{Remediating Education.}

For those of us working in media education, this is nothing new; Three decades ago, Len Masterman called for a media education for all, and that such teaching, "should not be confined to the province of media teachers. We need to think of it as a specialist subject in its own right, certainly, but also as an element which will need to inform the teaching of all subjects [original italics]" (1985: 241). As the following decades became increasingly technological, and therefore mediated, those such as David Buckingham argued that, "[c]hildhood is now permeated, even in some respects, by the modern media" (2007: 75). Such thinking called for a 'media-literacy-for-all' to be taught in schools, and while that term currently, "lacks adequate definition" (Bolas, 2009: 353), for Buckingham, "media literacy involves 'writing' the media as well as 'reading' them...quite young children can [now] easily produce multimedia texts" (2007: 163). If nothing else, Secret Life... makes these suggestions seem like common sense. 
In the 2015 Christmas Special, The Secret Life of Children at Christmas, children from The Secret Life of Six Year Olds were brought together with children from the original pilot programme (who were now aged six) as well as two children from The Secret Life of Four Year Olds. The central conceit here for the children, was to 'write' and create their own version of the Nativity. At first glance, this seems like the perfect illustration of Buckingham's suggestions. But, it is far from that, whilst paradoxically perhaps, demonstrating why such new person-centric, holistic media literacy education is increasingly needed.

In the episode, the children constantly refer to other media texts (such as Snow White). We see them drawing, and ultimately 'writing' the script for their own version of the Christmas play. This becomes the prompt for quite a sophisticated religious discussion between the children, with one, Cuba, calling Christianity a "fake fairy tale". The conversation continues about the validity of religious belief, with one child, Shakir taking very eloquently about his own Muslim faith, and how that segues with his own Muslim faith. Later, his parents (at home) explain how their faith co-exists with others. All of these exchanges pass without comment from the experts, but suggest a fairly high degree of media literacy. Similarly, the children are given a free reign for their audition pieces, and again, the textual lived-lives of the participants are never too far from the surface; one children performs a song from the musical/film, Phantom of the Opera, and another 'street dances' to their favourite tune. After a falling out, Cuba gives a present of a book of poetry to Shakir as a means of making up after their disagreement, and the two boys delight in reading nonsense rhymes to each other. The episode ends with the Nativity play, featuring a female 'Joseph' and the 'Angel Nigel' and is something of a missed opportunity.

All of the episodes of Secret Life... consistently demonstrate children's cross-platform media experiences. The children paint, draw and create media texts, finally resulting a play performed to parents, guardians and friends. As a text then, Secret Life... opens out and frames a range of situated 'utterances', from other media. Added to this is the children's play, which is often performance-based and 'adapted' from media texts, either fictional or factual (or both at the same time). As so much of 
children's television is now cross-platform, and adult television increasingly so, it seems strange that A Secret Life... is so medium specific, when the children's experiences are clearly not. For Bolter \& Grusin (2000), new digital forms of media act as management system for all other media, and "hypermedia" is the term they employ to demonstrate how an older media is represented in a newer one, but Secret Life... is an older medium (television) framing an array of utterances which are nothing less than how children represent themselves in other media.

\section{Remediating Pedagogy.}

As early as Mead (1913) there have been those that have noted the importance of social interaction on child development. Vygotsky (1978) argued that a social inter-relatedness helps shape cognitive development (Inhelder \& Piaget, 1962), and that through the 'cultural tools' of language and other sign systems, like media, children some to reproduce "the knowledge of generations" (Corsaro, 2011: 15). It was Vygotsky who made the first major contribution to educational studies augmenting social interaction as part of an 'activity' pedagogy (see Daniels, 2008). His body of work argued forcefully that higher mental functions develop through social interaction. The success of such approaches depends on 'internalization' where material initially outside and beyond the individual child are internalised through appropriation - this serves to make such experiences unique to the individual. Secret Life... is full of such moments, specifically when the children play using 'pretend' mobile phones in their interactions; making otherwise outside tools, their own. For Vygotsky, these tolls are 'pivots' on which learning hinge. Vygotsky developed this into his 'zone of proximal development' (ZPD), a far more holistic approach to learning where a child is set a range of tasks to complete, or finish. However, Secret Life... does not offer a mediated version of ZPD (nor does it make claims to) by privileging development over learning, and in this way seems constructivist in design.

Similarly, proponents of more experiential approaches, such as John Dewey, recognise that learning is a social and interactive process. But here, educational interventions are crucial; the curriculum and the teaching are the limits, which are imposed to combine to create a single process: "Unless experience is so conceived that the result is a plan for deciding upon subject matter, upon methods of 
instruction and discipline, and upon material equipment and social organization of the school, it is wholly in the air" (Dewey, 1997: 28). In Secret Life... there is no curriculum, and the 'tasks' are wholly to create conflict and to produce entertaining television. During the Nativity programme, the children are largely left alone to write and create their play; the two teachers only intervene to enforce discipline, while off-screen prompts asks the children to repeat things that they have said. None of the children normally interact with each other, and the episode covers a week, while the children attend a school during what would otherwise be their holidays. Essentially, the children in Secret Life... are experiencing little more than being in a reality television programme, rather than a sophisticated developmental and education experiment.

While Secret Life...then is not an educational television programme for adults, for the reasons outlined, it is perhaps fitting to frame a tentative distinction between 'media learning' and 'learning media', with Secret Life...displaying media learning opportunities not shaped in light of any formal learning outcome. There are examples within contemporary practice that span this distinction, and here S4C's Welsh language Ditectifs Hanes (History Detectives) (2012- present) television broadcast acts as media learning, in that it sets out to generally entertain and trigger interest, whilst its web based short films have been created to help teach the History of Wales (Key Stage 2) curriculum. Media learning and learning media rarely meet within one media phenomenon however, and UK children's media for the age group here is almost exclusively shaped around entertainment, not school-work imperatives.

Secret Life... could be conceived of as an attempt to position a television programme between factual and entertainment (although, as we have argued it perhaps erring far more toward entertainment). This leaves us questioning if children would respond to learning in more fictional settings, like Doctor Who, Star Wars or Pokémon. Here we might usefully turn to Swann's study whereby she asked child "participants to consider a television programme from which they had learned something and to draw a scene" from it (2013: 146). Within these interactions children: were just as likely to list dramas, whether live-action or animated (and including soaps and other non-children's formats) as 
they were to list the more obvious learning formats such as factual shows. Every time they watch a television show, they are prepared to learn (Ibid: 150).

Here it might also be worth adding that any singular media 'utterance' sits within a wider, often channel-led, repertoire of media engagement, and hence any particular production, whether perceived as more entertainment or learning facing, should be seen in relation to its surrounding offerings, and thus production level distinctions between fiction and factual, entertainment and educational, come in to question. This is something that Secret Life... has somewhat overlooked.

Nixon has noted how the "intertextual discourses of television, film, advertisements and lifestyle magazines [provide] a matrix of teaching and learning' opportunities" (1998: 23), and similarly transmedial cross-platform engagement has recently come in to focus pedagogically:

through immersive, interconnected, and dynamic narratives, trans-media engages multiple literacies, including textual, visual, and media literacies, as well as multiple intelligences. It is highly engaging and allows for important social sharing among collaborators (Herr-Stephenson \& Alper, 2013: 2). Transmedia in a participatory, playful and constructivist sense "encourages additive comprehension. We learn something new as we follow the story across media" (Jenkins, 2013: 7). Such transmedial learning possibilities promise much.

Looking back to Vygotsky (1978), when he acknowledges the importance of action in learning, we could infer that more interactive, transmedial, and 'hands-on' media engagement allows children to actively co-construct meaning across platforms in intriguingly learning rich ways. Vygotsky (1978, 1998) and Winnicott (1971) likewise suggest that play, in particular imitative and creative play, is vital in a child's cognitive development, and again we could see more interactively playful media as offering opportunities for learning, which came as something of a surprise to the reviewers of Secret Life..., many of whom still seemed wedded to effects approaches to the media: "Many parents try to protect their children from distressing news...But Secret Life Of Six Year Olds shows they may learn from their friends" (Waterlow, 2015). 
Toward a Performance Pedagogy.

In a sense, while The Secret Life of Six Year Olds largely fails as a piece of pedagogy, it does serve as the perfect illustration of what work now needs to be done. It is clear from watching Secret Life..., that children's lived experience of the world in inherently textual and mediated; both factual and fictional media texts are used as sources for performance play, from acting out news programmes, based on recent events, to constructing a version of the Christmas Nativity narrative. The children in Secret Life... are continually assembling and creating their own texts, from a bricolage of media experiences, and this has implications for pedagogy: "For all ages this involves engaging and developing skills and dispositions which enable agency in some way; curatorship is to curation as authorship is to writing. New or adapted skill sets in new media are nascent in people of all ages but suggest certain ways of being and learning for younger people in formal or informal settings of learning" (Potter \& Gilje, 2015). If nothing else, at a time when the UK school curriculum is being redrawn under very narrow lines of what constitutes 'literacy', Secret Life... suggests that such definitions need to now take account for the adaptation/appropriation and curation of media texts, in children's performance play, as new Vygotskyian 'pivots'. The challenge for educators now, is that curriculum interventions are now out of step, as shown by the lack of diegetic commentary from the Secret Life... 'experts' on the children's mediated performance play, and the genuine surprise at such outcomes in critical reviews of the television programme.

Researchers working in more textual and literary fields, have long called for a redefinition of literacy which takes into account these practices, and have done much to advance the pedagogic reach of their work; Thomas Leitch, agues that an understanding of adaptation is 'essential' for any literacy education and he points out that adaptation studies focuses on both reading and writing: "students who become more proactive in creating their own texts will find themselves not only writing with greater authority but speaking and performing more inventively, fearlessly, and constructively" (2010: 11). Like Buckingham (2007), Berger (2010) proposes a pedagogy whereby students are given material to re-write. But, all of these interventions and debates are taking place the high school curriculum. To 
date, as Secret Life... highlights, there is a lack of research in now adaptation can be effectively used as a pedagogic tool in the primary school classroom.

This strikes us as odd, for any cursory look at children's media, demonstrates that literacy, re-writitng and appropriation a dominant activity, as Secret Life... explicitly demonstrates. In addition, children's media is a rich field of never ending adaptation, recycling and appropriation; texts such as Danger Mouse (1981 - 1992) and Paddington (1975 - 1986) are just recent examples of this phenomena, having both been 'rebooted' for a new generation of children (and in a way which asynchronously segues with their parents' textual lives). As Cartmell notes, "[c]hildren, unlike adults, love to re-read their favourite stories" (2007: 169). And it is this demand for repetition, which is ignored in education (which hurries from text-to-text, from subject-to-subject). Writers such as Collins suggests that electronic media has fundamentally changed our definitions of reading and literacy: "we are all curators now of words and images" (2010: 266).

Secret Life... demonstrates in ways which surprised viewers and commentators, that a great deal of children's 'play' can be conceived of as remaking, or re-writing; even in such contrived and artificial a space as a reality television programme, children can be seen to be performing quite sophisticated textual acts, which in many ways embody Fiske's (1992) notions of “producerly" or even Barthes' conceptions of "writerly" (1974) texts: "[texts] have to be pen, to contain gaps, irresolutions, contradictions, which both allow and invite fan productivity" (Fiske 1992: 41-42). That these types of performances are still under-represented in pedagogic scholarship is for us a cause for concern.

\section{The Secret Life of Pedagogy.}

In all fairness, The Secret Life of Six Year Olds, and its attendant variants, never presented themselves as a 'purely' educational experiments; all of the Secret Lives...programmes owe far more to the genres of reality television and texts like Googlebox and YouTube channels such as 'Kids do the Funniest Things' and Buzzfeed 'listicles' like '19 of the Funniest Things Kids Have Said'. However, Channel 4 is a mainstream UK television channel, with a clear public service broadcast remit and the production 
company who made Secret Life... has a rich history of providing quality factual programming, with an educational slant.

The featuring of child development and educational 'experts' served a broader agenda than just adding an informed commentary on the events and conflicts taking place during each episode. These experts became deputised as spokespeople for the programme; they featured on news and lifestyle programmes on other channels to talk about the show and were quoted at length in both print and online media. It was this 'chatter' which while mobilised by Secret Life... was the start of a national conversation which (albeit briefly) covered comparisons with other media texts from the reality TV and soap opera genres - fuelled by the relationships between the children - and education. Similarly, the two teachers made few pedagogic interventions and acted more as 'curators' of the children's activities and outputs. As the influence on children of media texts became more apparent particularly with the six-year olds - as sources for performance play (which often involved appropriation and re-writing) the lack of commentary on this was telling; if Secret Life... was an attempt at 'pedagogy by stealth' then it was far more interesting for what was not discussed, than for what was.

In a sense, the classroom featured in Secret Life... became the type of "imaginary museum" described by Fredric Jameson; a "simulacra" of an educational experience, presided over by the teachers and 'experts' which was always going to mobilise pedagogic discourses. However, he warns of such scenarios that: "The logic of the simulacrum with its transformation of older realities into television images, does more than merely replicate the logic of late capitalism; it reinforces and intensifies it...which by transforming past visual images, stereotypes or texts, effectively abolishes any practical sense of the future and of the collective project, thereby abandoning the thinking of future changes to fantasies of catastrophe and inexplicable cataclysm" (2000: 225). In this he perhaps echoes both Vygotsky (1978) and Dewey (1997) who both recognise that education and learning is inherently mediated, and that therefore mediated experiences need carefully thought through and pedagogically informed interventions. 
The exhibition and reception of the Secret Life of Six Year Olds suggests to us that children have a far more complex and sophisticated relationship with media texts than is currently given credit by educators and current pedagogic scholarship. These interactions with media texts, are often through appropriation, remaking and re-writing, and are (currently) activities which education and learning does not (yet) account for, let alone put at the centre of pedagogic research. It has taken a reality television programme to make explicit to a national audience something long known by media education and media literacy researchers. Secret Life... revealed much about the ways in which children relate to their life-world, and each other, through an array of complex textual negotiations. The challenge for us now is to completely remediate pedagogy is ways which account for these interactions as Vygotskian 'tools' and in ways which are part of an 'twin-track' approach to experiential learning proposed by Dewey; with experience and curriculum interventions sharing the same horizon. The irony is perhaps, that it has taken a television programme, which lacks any real pedagogic heft, to demonstrate this. 
Bibliography.

Barker, M \& Petley, J, eds., 1997. III Effects: the media violence debate. London: Routledge.

Barthes, R., 1974. S/Z. Oxford: Blackwell.

Berger, R., 2010. 'Never Seek to Tell Thy Love: E-adapting Blake in the Classroom.' In: Cutchins, D, Raw, L \& Welsh, J, M, eds, Redefining Adaptation. Lanham: The Scarecrow Press.

Bolas, T., 2009. Screen Education: from film appreciation to media studies. Bristol: Intellect.

Bolter, J, D \& Grusin, R., 2000. Remediation: understanding new media. Massachusetts: MIT Press.

Buckingham, D., 2007. Beyond Technology: children's learning in the age of digital culture. Cambridge: Polity.

Cartmell, D., 2007. 'Adapting Children's Literature.' In: Cartmell, D \& Whelehan, I, eds, The Cambridge Companion to Literature on Screen. Cambridge: Cambridge University Press.

Collins, J., 2010. Bring on the Books for Everybody: how literary culture became popular culture. London: Duke University Press.

Cox, E., 2015. 'Inside the secret life of four-year-olds'. In: The Sun, $10^{\text {th }}$ November.

Daniels, H., 2008. Vygotsky and Pedagogy. London: Routledge.

Dewey, J., 1997. Experience \& Education. New York: Touchstone. 
Fiske, J., 1992. 'The Cultural Economy of Fandom.' In: Lewis, L, A, ed, The Adoring Audience. London: Routledge.

Herr-Stephenson, B \& Alper, M., 2013. T is for Transmedia: Learning through Transmedia Play. USC Annenberg Innovation Lab \& The Joan Ganz Cooney Center at Sesame Workshop. Available from: http://www.joanganzcooneycenter.org/wp-content/uploads/2013/03/t_is_for_transmedia.pdf [Accessed: 10 December 2015]

Inhelder, B \& Piaget, J., 1962. The Psychology of the Child. New York: Basic Books.

Jameson, F., 2000. Postmodernism, or The Culural Logic of Late Capitalism. In: Hardt, M \& Weeks, K, eds, The Jameson Reader. Oxford: Blackwell.

Jenkins, H., 2013. 'Introduction'. In: T is for Transmedia: Learning through Transmedia Play. USC Annenberg Innovation Lab \& The Joan Ganz Cooney Center at Sesame Workshop. Available from: http://www.joanganzcooneycenter.org/wp-content/uploads/2013/03/t_is_for_transmedia.pdf [Accessed: 10 December 2015]

Leitch, T., 2007. Film Adaptation and its Discontents: From Gone with the Wind to The Passion of the Christ. Baltimore: Johns Hopkins University Press.

London, B \& Johnston, J., 2015. 'A playground marriage, a boy coping with the death of his mother and LOTS of kissing: Eye-opening show reveals hilarious and tear-jerking behaviour of four-year-olds in Big Brother style documentary'. In: The Daily Mail, $10^{\text {th }}$ November.

Masterman, L., 1985. Teaching the Media. London: Routledge. 
Mead, G. H., 1913. 'The Social Self'. In: Journal of Philosophy, Psychology and Scientific Methods. 10. pp. 374- 380. Available from: http://www.brocku.ca/MeadProject/Mead/pubs/Mead_1913.html [Accessed: December 10 2015]

Potter, J \& Gilje, O., 2015. 'Curation as a new literacy practice'. In: E-Learning \& Digital Media. 12 (2), pp. 1-6.

Swann, A., 2013. 'Make up Your Favourite TV Host: Discussion of The UK Element of a Global Study on Children's Television Presenters'. In: The Children's Media Yearbook 2013. L. Whitaker, ed. London: The Children's Media Foundation.

Vygotsky, L. S. 1978. Mind in Society: The Development Of Higher Psychological Processes. Cambridge, MA: Harvard University Press.

Waterlow, L., 2015. "'There was a blow up and lots of people died": How children as young as SIX are discussing terrorism in the playground and are turning what they learn into games'. In: The Daily Mail, $10^{\text {th }}$ December.

Winnicott, D, W., 1971. Therapeutic Consultations in Child Psychiatry. New York: Basic Books.

Wollaston, S., 2015. 'The Secret Life Of Five Year Olds review: What must their parents be thinking?'. In: The Guardian, $20^{\text {th }}$ November.

Woods, J., 2015. 'The secret life of four- to six-year-olds: what really goes on in the playground'. In: The Daily Telegraph, $30^{\text {th }}$ October.

Wyatt, D., 2015. 'The Secret Life of Four-Year-Olds, Channel 4 - TV review: Too many tantrums and not enough insight'. The Independent, $3^{\text {rd }}$ November. 